\title{
Cogging Force Verification of the Back-yoke Length of a Moving-coil-type Slotless Linear Synchronous Motor
}

\author{
Yong-Jae Kim ${ }^{1}$ and Sang-Yong Jung ${ }^{2 *}$ \\ ${ }^{1}$ Department of Electrical Engineering, Chosun University, Gwangju 501-759, Korea \\ ${ }^{2}$ Department of Electrical Engineering, Dong-A University, Busan 604-714, Korea
}

(Received 28 October 2008, Received in final form 2 February 2009, Accepted 4 February 2009)

\begin{abstract}
The coreless linear synchronous motor (coreless LSM) has been widely used as a driving source of semiconductor production processes for machine speeding up, positioning accuracy and simple maintenance. However, this coreless LSM suffers the disadvantage of decreased thrust force created by the leakage of magnetic flux. With the goal of increasing the generated thrust force and decreasing the cogging force, the slot of the core part was removed and a moving-coil-type slotless LSM (moving-coil-type slotless LSM) is proposed in this paper. Although this moving-coil-type slotless LSM with a back-yoke at the primary side demonstrated an increase in the generated thrust force, it remained capable of generating the cogging force when the primary side was moved due to the position between the permanent magnet and the back-yoke. Therefore, we attempted to decrease the cogging force of the moving-coil-type slotless LSM. We found that the back-yoke length at the primary side needs to be made $0.5 \tau$ longer than the integral multiple of the magnetic pole pitch in order to decrease the cogging force created by the moving-coil-type slotless LSM.
\end{abstract}

Keywords : moving-coil-type, slotless linear synchronous motor, cogging force, back-yoke length

\section{Introduction}

Permanent magnets using high-energy products have been applied to various systems [1-3]. Systems using permanent magnets with high-energy products have been produced and distributed mainly through the factory automation field $[4,5]$. Particularly, linear motors have been developed as a mainstream in this field. Currently, permanent-magnet-type linear synchronous motors (PM-LSMs) are used as a driving source for transportation systems to satisfy requirements such as high-speed, low noise, and simplification of the driving apparatus for transportation systems, and to simplify maintenance [6-9].

PM-LSMs are classified into two types of motor: cored and coreless. The former has a large thrust force, the production of thrust force ripples from the cogging force. The latter has an excellent control without the cogging force, in spite of the small thrust force. Therefore, coreless motor types are utilized in the fields of semiconductor production process and short-distance transportation systems $[10,11]$. In contrast to the cored motors, the coreless

*Corresponding author: Tel: +82-51-200-7733

Fax: +82-51-200-7743, e-mail: syjung@dau.ac.kr motor type cannot utilize the thrust force efficiently as most of the generated magnetic flux leaks away.

In order to decrease the cogging force of the cored motor type and increase the thrust force of the coreless motor type, the moving-coil-type slotless LSM (movingcoil-type slotless LSM) is proposed in this paper. This motor type increases the generated thrust force because of the back-yoke at the primary side, but continues to generate the cogging force when the primary side is moved due to the position between the permanent magnet and the back-yoke. In order to decrease the cogging force of the moving-coil-type slotless LSM, we investigated a method to regulate the length of the back-yoke at the primary side. This paper presents the experimental results of length regulation of the back-yoke at the primary side to decrease the cogging force in the moving-coil-type slotless LSM.

\section{Moving-coil-type slotless linear synchronous motor}

\subsection{Appearance of the experimental device}

The experimental device is shown in Fig. 1(a). The cross-sectional diagram of the primary and secondary sides 


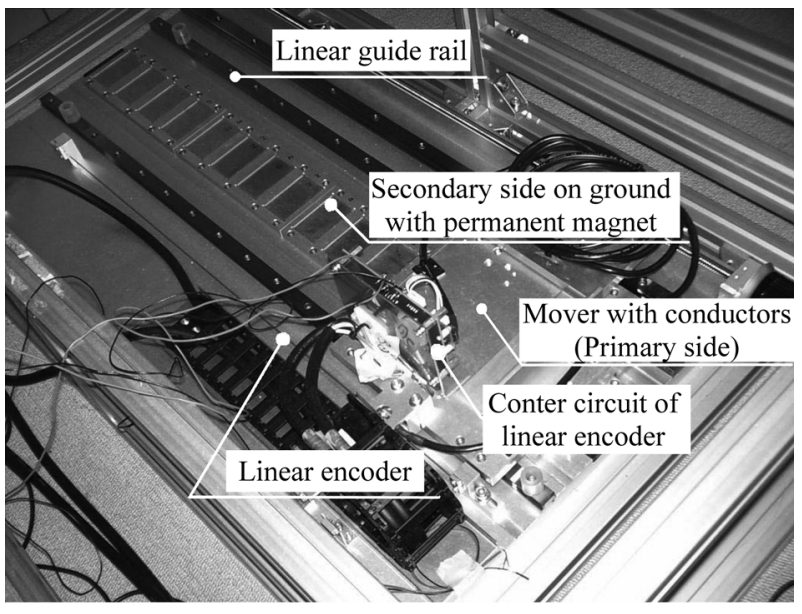

(a)

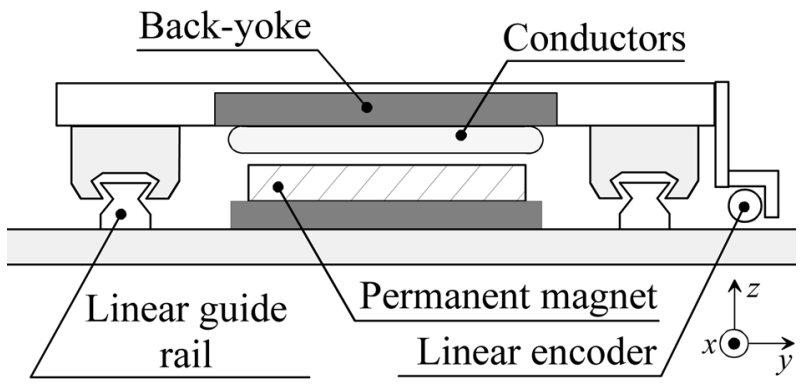

(b)

Fig. 1. Experimental device: (a) outline of experimental device and (b) cross-sectional diagram of the primary and secondary sides.

Table 1. Experimental device specifications.

\begin{tabular}{lcc}
\hline \multicolumn{1}{c}{ Parameter } & Unit & Value \\
\hline Primary side & & \\
$\quad$ Number of conductors & $y_{\text {coil }}$ & 3 \\
$\quad$ Coil pitch & $\tau_{c}(\mathrm{~mm})$ & 53.3 \\
$\quad$ Number of turns & $n$ (turn) & 280 \\
& & \\
Secondary side & $y_{\text {magnet }}$ & 16 \\
$\quad$ Number of magnets & $\tau_{p}(\mathrm{~mm})$ & 40 \\
$\quad$ Pole pitch & $\mathrm{BH}_{\max }\left(\mathrm{kJ} / \mathrm{m}^{3}\right)$ & 287 \\
$\quad$ Maximun energy product & & \\
& $g(\mathrm{~mm})$ & 1 \\
Air-gap &
\end{tabular}

is shown in Fig. 1(b). Table 1 presents the specification of the experimental device. The length of the experimental device and the primary side were $640 \mathrm{~mm}$ and $160 \mathrm{~mm}$, respectively. The ratio of the magnetic pole pitch of the permanent magnet to the coil was 4 to 3 . The 16-pole permanent magnet was set up at the secondary side and three-phase conductors were set up at the primary side. The magnetic pole pitch $(\tau)$ at the secondary side was $40 \mathrm{~mm}$ and the permanent magnets provided $(\mathrm{BH})_{\max }$ of $287 \mathrm{~kJ} / \mathrm{m}^{3}$. The coil pitch at the secondary side was $53.3 \mathrm{~mm}$ and a linear guide rail was used as a supporting mechanical instrument.

\subsection{Cogging force of the moving-coil-type, slotless lin- ear synchronous motor}

In this section, the cogging force of the moving-coiltype slotless LSM is investigated by experimental data. Fig. 2 is a schematic showing the cogging experimental device. The cogging force was the air-gap of the secondary side and the primary side was fixed at an interval of 1 $\mathrm{mm}$. The cogging force was then measured by the 2-mm movement of the primary side. The position of the primary side was measured using an absolute linear encoder and the cogging force was measured using a load cell with a measuring range of $98 \mathrm{~N}$. The initial position of the primary side was the matched position of an $\mathrm{S}$ pole center and U-phase coil center in the permanent magnet. The length of the back-yoke at the primary side was 160 $\mathrm{mm}$ in this experiment. The angle with the position of the mover calculated electrically was expressed as the electrical angle, i.e., the angle which the position of the mover is expressed electrically by 1 cycle of sinusoidal AC with $360^{\circ}$. The experimental result of the cogging force is shown in Fig. 3(a), and the position relationship between the primary and secondary sides is shown in Fig. 3(b). Fig. 3(a) reveals that the cogging force had an invariable periodicity and that it was generated in the $1 \tau$ pole pitch period of the permanent magnet. The maximum cogging force of the moving-coil-type slotless LSM was $44.3 \mathrm{~N}$ when the air-gap was $1 \mathrm{~mm}$. The generated cogging force was considered as an attractive force of position relationship between the back-yoke and the permanent magnet. From Fig. 3(b), the 160-mm back-yoke length, which was four times the length of the 40-mm magnetic pole pitch of the permanent magnet, was the same as the magnetic edge of the back-yoke from the position relationship between the back-yoke and the permanent magnet. The maximum

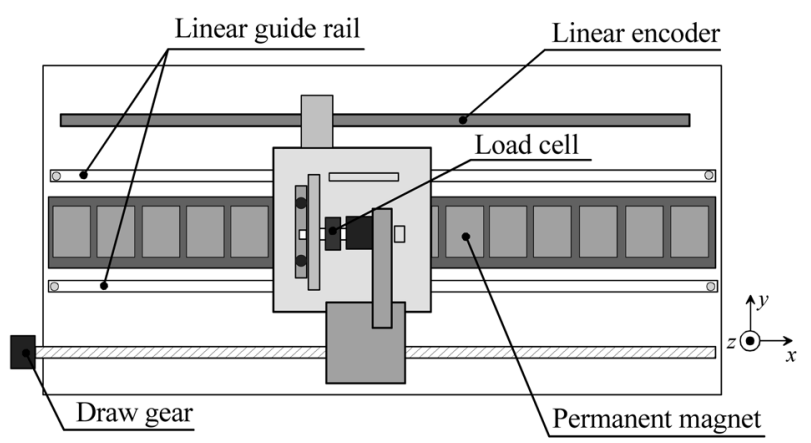

Fig. 2. Measurement device. 


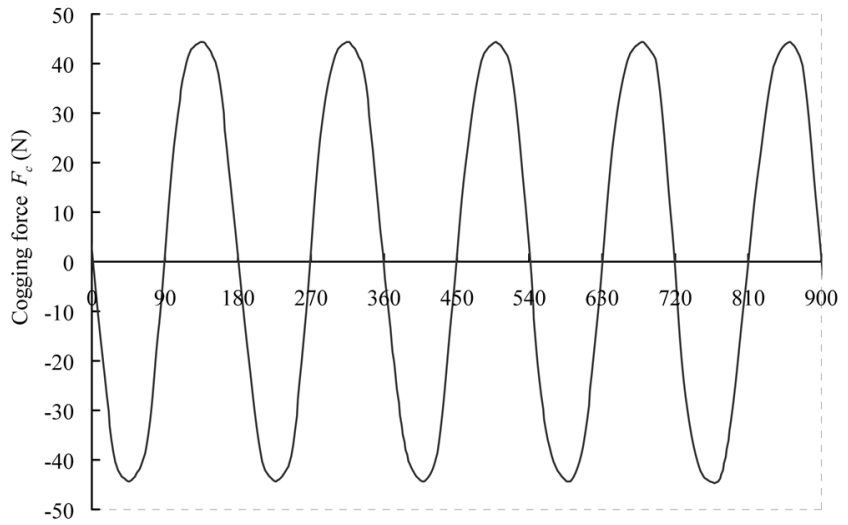

Electrical angle $\theta$ (deg.)

(a)

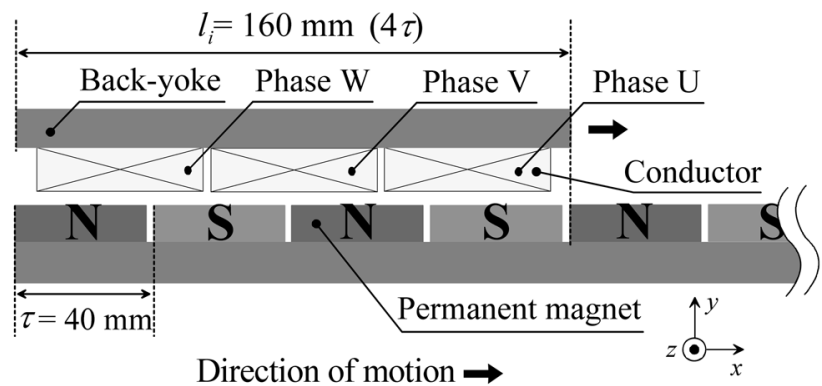

(b)

Fig. 3. Cogging force waveform: (a) cogging force at the 160$\mathrm{mm}$ back-yoke length, and (b) the position relationship between the primary and secondary sides.

cogging force of $44.3 \mathrm{~N}$ was considered to have been generated from the attractive force between the back-yoke edge and the magnetic edge.

\section{Cogging Force Decreasing Method of the Moving-coil-type Slotless Linear Synchronous Motor}

In order to decrease the cogging force generated by the moving-coil-type slotless LSM, the back-yoke length was regulated within a $4 \tau \sim 5 \tau(160 \mathrm{~mm} \sim 200 \mathrm{~mm})$ range of the permanent magnetic pole pitch. Then, the cogging force for each back-yoke length was investigated. Fig. 4(a) shows a model regulated by the back-yoke length within the $4 \tau \sim 4.5 \tau(160 \mathrm{~mm} \sim 180 \mathrm{~mm})$ range of the permanent magnetic pole pitch. Fig. 4(b) shows the characteristics of the cogging force of each model regulated by the backyoke length within the $4 \tau \sim 4.5 \tau$ range of the permanent magnetic pole pitch. The same experimental method and initial position of the primary side were used as in section 2.2. From Fig. 4(b), the cogging force of the moving-coiltype slotless LSM was decreased more than the $160-\mathrm{mm}$ back-yoke length. When the back-yoke length was 160
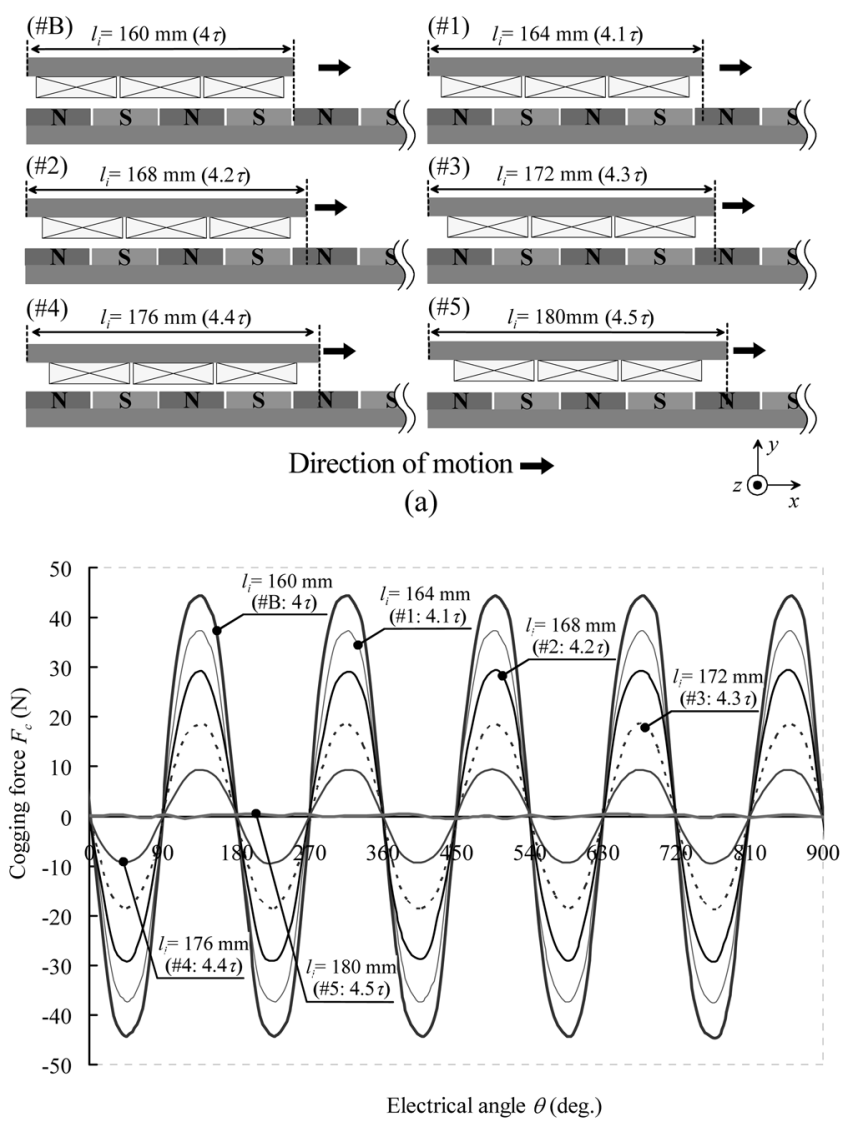

(b)

Fig. 4. Cogging force waveforms as a function of the backyoke length within a $4 \tau \sim 4.5 \tau(160 \mathrm{~mm} \sim 180 \mathrm{~mm})$ range of the permanent magnetic pole pitch: (a) model regulated by the back-yoke length within the $4 \tau \sim 4.5 \tau$ range, and (b) characteristics of the cogging force of each model.

$\mathrm{mm}$ for the permanent magnetic pole pitch of $40 \mathrm{~mm}$, the generated cogging force was $44.3 \mathrm{~N}$. Among the regulated models of the back-yoke length, only the $180-\mathrm{mm}$ model generated a cogging force of $0.41 \mathrm{~N}$.

Next, the characteristics of the cogging force were investigated when the back-yoke length was within a $4.5 \tau \sim 5 \tau$ $(180 \mathrm{~mm} \sim 200 \mathrm{~mm})$ range of the permanent magnetic pole pitch. A regulated model of the back-yoke within the $4.5 \tau \sim 5 \tau$ range of the permanent magnetic pole pitch is shown in Fig. 5(a). Fig. 5(b) shows the characteristics of the cogging force of each model regulated by the backyoke length within the $4.5 \tau \sim 5 \tau$ range of the permanent magnetic pole pitch. Fig. 5(b) demonstrated that the cogging force was increased when the back-yoke length was more than $4.5 \tau$ of the permanent magnetic pole pitch. Fig. 6 shows the characteristics of the cogging force for the back-yoke length proposed in this paper. As shown in the figure, the cogging force generated by the back-yoke length with a focus on the 180 -mm back-yoke length was 


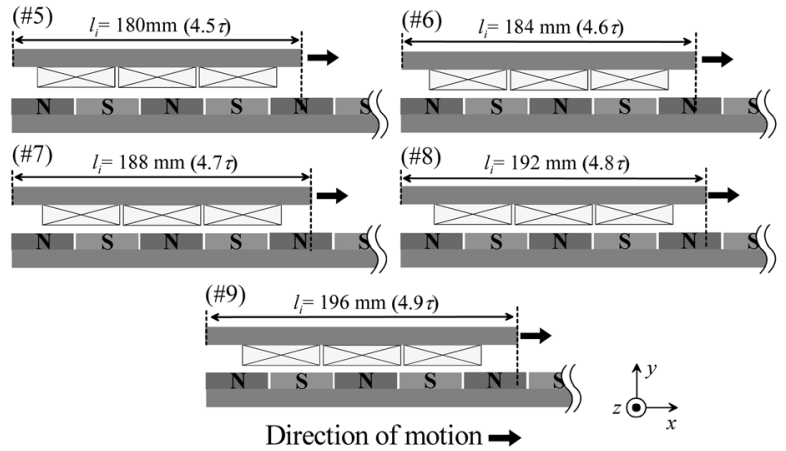

(a)

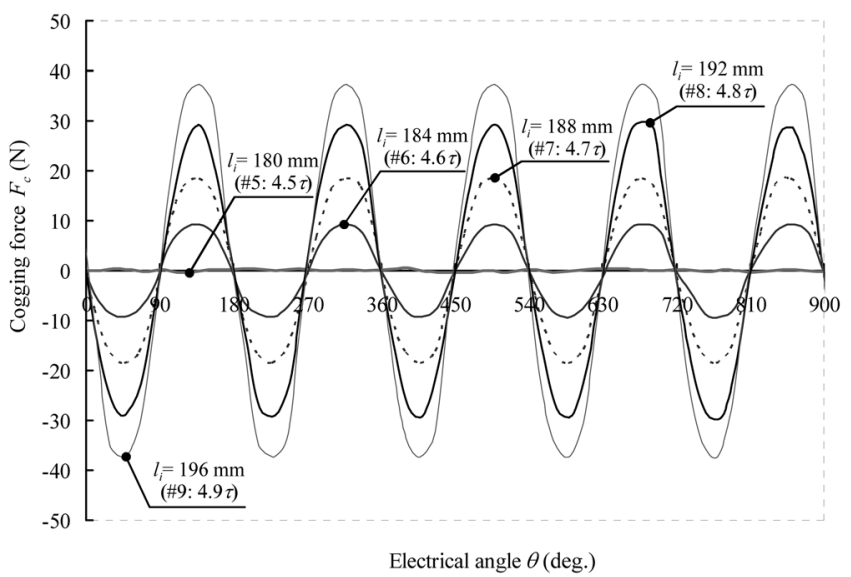

(b)

Fig. 5. Cogging force waveforms as a function of the backyoke length within a $4.5 \tau \sim 5 \tau(180 \mathrm{~mm} \sim 200 \mathrm{~mm})$ range of the permanent magnetic pole pitch: (a) model regulated by the back-yoke length within the $4.5 \tau \sim 5 \tau$ range, and (b) characteristics of the cogging force of each model.

symmetrical.

When the back-yoke length for the magnetic pole pitch was regulated to $4 \tau$ and $5 \tau$, the cogging forces generated at both edges of the back-yoke was summed up to the total cogging force as both forces have same phase. However, when the back-yoke length for the magnetic pole pitch was regulated to $4.5 \tau$, the phase relationship of the cogging force generated by both edges of the back-yoke was reversed mutually. This action was considered to have cancelled the total cogging force.

\section{Conclusion}

In order to decrease the cogging force and increase the generated thrust force, a moving-coil-type slotless LSM was investigated in this paper. The maximum generated cogging force was $44.3 \mathrm{~N}$ for the $160-\mathrm{mm}$ back-yoke length with an air-gap of $1 \mathrm{~mm}$. Then, we focused on the back-yoke length at the primary side in order to decrease

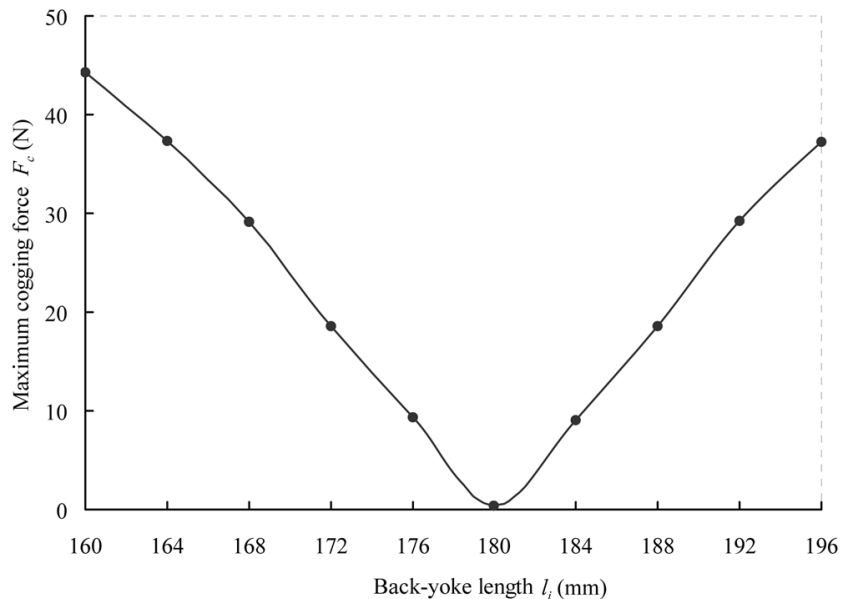

(a)

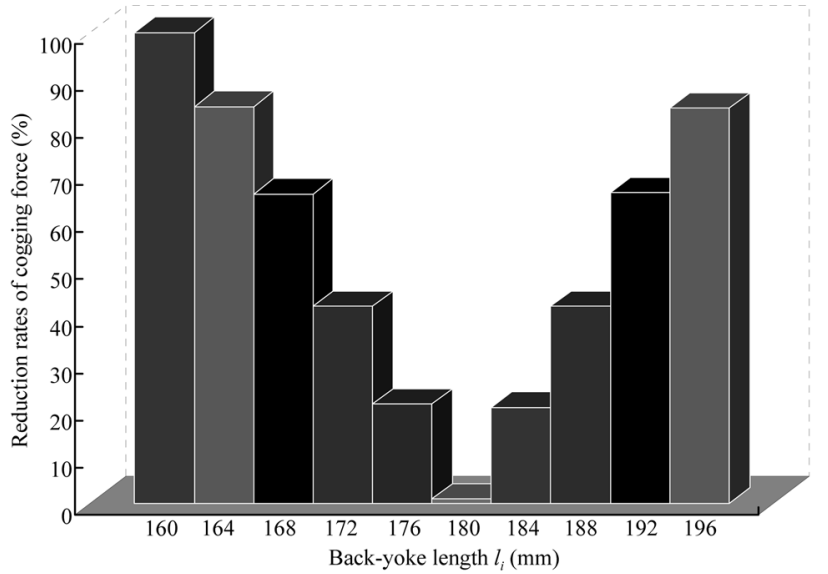

(b)

Fig. 6. Characteristics of the cogging force as a function of the proposed back-yoke length: (a) maximum cogging force according to the back-yoke length within a $4 \tau \sim 5 \tau$ range, and (b) reduction rates of cogging force according to the back-yoke length.

the cogging force that influences the machine output and driving characteristics.

The characteristics of the cogging force according to the back-yoke length $\left(l_{i}\right)$ were investigated with backyoke length regulation, with the following results:

1) Case of $4 \tau \leq l_{i} \leq 4.5 \tau$ : the cogging force was decreased with increasing back-yoke length $\left(l_{i}\right)$.

2) Case of $4 \tau \leq l_{i} \leq 5 \tau$ : the cogging force was increased with increasing back-yoke length $\left(l_{i}\right)$.

Among the regulated models, that with the $180-\mathrm{mm}$ (4.5 $\tau$ ) back-yoke length exhibited the most decreased cogging force: its cogging force of $43.9 \mathrm{~N}$ represented a $93 \%$ decrease of the total cogging force compared to the $160-\mathrm{mm}$ back-yoke length with the $40-\mathrm{mm}$ permanent magnetic pole pitch. We found that the back-yoke length must be $0.5 \tau$ longer than the integral multiple of the 
magnetic pole pitch in order to decrease the cogging force generated by the moving-coil-type slotless LSM.

\section{Acknowledgements}

This study was supported by research funds from Dong-A University.

\section{References}

[1] S. Bae, Y. Hong, J. Lee, G. Aavin, J. Jalli, A. Lyle, H. Han, and G. W. Donohoe, J. Magnetics 13, 37 (2008).

[2] S. Hisatomi, A. Yamazaki, K. Ishiyama, M. Sendoh, S. Yabukami, S. Agatsuma, K. Morooka, and K. Arai, J. Magnetics 12, 84 (2007).

[3] A. Chiba, M. Sendoh, K, Ishiyama, K, Arai, H. Kawano, A. Uchiyama, and H. Takizawa, J. Magnetics 12, 89 (2007).

[4] M. Lee, M. Lee, S. Lee, and D. Gweon, J. Magnetics 6, $101(2001)$.

[5] D. Son, J. Magnetics 8, 93 (2003).

[6] F. Lin, P. Shen, and Y. Kung, IEEE Trans. Magnetics 41,
4401 (2005).

[7] T. Mizuno and H. Yamada, IEEE Trans. Magnetics 28, 3027 (1992).

[8] R. Akmese and J. F. Eastham, IEEE Trans. Magnetics 28, 3042 (1992).

[9] M. Sanada, S. Morimoto, and Y. Takeda, IEEE Trans. Industry Appl. 33, 966 (1997).

[10] R. Wang and M. Kamper, IEEE Trans. Energy Conversion 19, 532 (2004).

[11] M. Ooshima, S. Kitazawa, A. Chiba, T. Fukao, and D. Dorrell, IEEE Trans. Magnetics 42, 3461 (2006).

[12] T. S. Low, M. A. Jabbar, and T. S. Tan, IEEE Trans. Industry Appl. 3, 43 (1997).

[13] S. Y. Jung, J. S. Chun, and H. K. Jung, IEEE Trans. Magnetics 37, 3757 (2001).

[14] M. Y. Kim, Y. C. Kim, and G. T. Kim, IEEE Trans. Magnetics 39, 2989 (2003).

[15] N. Bianchi, S. Bolognani, and F. Luise, IEEE Trans. Power Electronics 21, 1083 (2006).

[16] S. I. Kim, J. P. Hong, Y. K. Kim, H. Nam, and H. I. Cho, IEEE Trans. Magnetics 42, 1219 (2006). 